In the tradition of the HogENDORPcentre, the European Constitutional Law Review (EuConst) follows the classical approach of constitutionalism, to discuss EU law's developments as well as comparative public law of the member states, political and constitutional theory and history. The journal is a platform for scholarly discussion of European constitutional events and evolution. It is open to contributions in this field from any country in the world and from any discipline. These contributions should satisfy as to substance, apart from the common scholarly criteria, two specific conditions, to a) have a distinctly European relevance and b) include a reference to and discussion of legal aspects involved.

\title{
Submission of Material
}

Authors are requested to send their manuscript to the Editorial Office European Constitutional Law Review, c/o Hogendorpcentre, P.O. Box 1030; NL - 1000 BA Amsterdam, E-mail: EuConst@uva.nl. All submitted materials should be in English. Materials may be submitted at any time of the year and, if accepted for publication, will be published at the earliest available opportunity.

\section{Copyright}

Copyright is exclusively vested in EuConst and the author(s) jointly. Acceptance of the Board of Editors' offer to publish implies, however, that authors agree to an embargo on publication elsewhere, either in English or another language, for a period of two years following the date of publication in EuConst. The agreement of the Board of Editors will be necessary before the article can be subsequently published elsewhere.

\section{Revision}

Articles accepted will be edited, linguistically and substantively, subject to author's approval.

\section{Books for Review}

These should be sent to Dr. Lars Hoffmann, Tilburg Institute of Comparative and Transnational Law (тісом), Tilburg University, P.O. Box 90153, 5000 LE Tilburg, the Netherlands. E-mail: Lars.Hoffmann@uvt.nl.

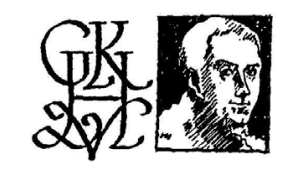

The G.K. van Hogendorpcentre for European Constitutional Studies, short: Hogendorpcentre, is a Jean Monnet centre of excellence at the University of Amsterdam. Founded in 1996, it promotes research and course development in the field of European Constitutional Studies, bringing together the disciplines of constitutional (including comparative) law, history, political theory. Gijsbert Karel van Hogendorp, 1762-1834, is the auctor intellectualis of the Dutch Kingdom's first constitution, of 1814.

Apart from editing the European Constitutional Law Review, the HogENDORPcentre hosts or cohosts yearly conferences and runs a series of publications, the Hogendorp-papers, published by Europa Law Publishing <http://www.europalawpublishing.com/european_law/erad.htm>. 


\section{CAMBRIDGE J JUNALS}

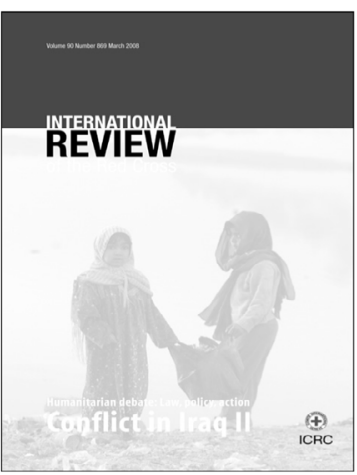

International Review of the Red Cross

is available online at:

http:/ljournals. cambridge.org/irc

\section{To subscribe contact}

Customer Services

in Cambridge:

Phone $+44(0) 1223326070$

Fax $+44(0) 1223325150$

Email journals@cambridge.org

in New York:

Phone +1 (845) 3537500

$\mathrm{Fax}+1$ (845) 3534141

Email

subscriptions_newyork@cambridge.org

\section{INTERNATIONAL REVIEW of the Red Cross}

\section{Editor-in-Chief}

Toni Pfanner, The International Committee of the Red Cross, Switzerland

The International Review of the Red Cross promotes reflection on humanitarian law, policy and action in armed conflict and other situations of collective armed violence. A specialized journal in humanitarian law, it endeavours to promote knowledge, critical analysis and development of the law and contribute to the prevention of violations of rules protecting fundamental rights and values.

Price information is available at: http://journals.cambridge.org/irc

\section{Free email alerts}

Keep up-to-date with new material - sign up at http://journals.cambridge.org/alerts

For free online content visit: http://journals. cambridge. org/irc 


\section{EUROPEAN CONSTITUTIONAL LAW REVIEW}

2OIO Volume 6 Issue I

\section{Contents}

\section{Editorial}

From Confederacy to Convoy: Thoughts about the finality of the Union and its member states 1

Articles

Susanna Mancini - The Crucifix Rage: Supranational Constitutionalism: Bumps Against the Counter-Majoritarian Difficulty 6

Bogdan IANCU - Post-Accession Constitutionalism With a Human Face: Judicial Reform and Lustration in Romania 28

Carlo Panara - In the Name of Cooperation: The External Relations of the German Länder and Their Participation in the EU Decision-Making 59 Arjen W.H. MeIJ - Circles of Coherence: On Unity of Case-Law in the Context of Globalisation 84

Xabier Arzoz - Accommodating Linguistic Difference: Five Normative Models of Language Rights 102

\section{Case Notes}

Chloé Charpy - France. The Conseil d'Etat Abandons Its Cohn Bendit CaseLaw; Conseil d'Etat, 30 October 2009, Mme Perreux 123

Sara Poli - European Court of Justice. The Legal Basis of Internal Market Measures With a Security Dimension. Comment on Case C-301/06 of 10 February 2009, Ireland v. Parliament/Council 137

Book reviews

Aileen Kavanagh - Constitutional Review Under the UK Human Rights Act (Gerhard VAN DER SCHYFF) 158

Mitchel DE S.-O.-L'E. Lasser - Judicial Transformations: The Rights Revolution in the Courts of Europe (Elaine MAK) 163

Distributed by:

\section{CAMBRIDGE} UNIVERSITY PRESS

\section{Cambridge Journals Online} journals.cambridge.org

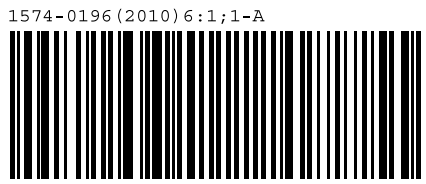

